\title{
CORPORATE SOCIAL RESPONSIBILITY AND REAL EARNINGS MANAGEMENT: DOES BOARD GENDER DIVERSITY MATTER?
}

\author{
Dr. Sonia Boukattaya \\ Corporate Governance, Applied Finance and Audit Laboratory \\ Higher Institute of Management of Tunis, University of Tunis, Tunis, Tunisia \\ E-mail: sonia.boukattaya@icloud.com \\ iD https://orcid.org/0000-0003-2223-7650 \\ Dr. Sameh Halaoua \\ Corporate Governance, Applied Finance and Audit Laboratory \\ Higher Institute of Management of Tunis, University of Tunis, Tunis, Tunisia \\ Accounting and Finance department, Higher Institute of Management of Sousse \\ University of De Sousse, Sousse, Tunisia \\ E-mail: halaoua.ahmed@gmail.com \\ https://orcid.org/0000-0002-5762-3642
}

Received: November 25, 2021

DOI: 10.46281/ijafr.v10i1.1635
Accepted: January 27, 2021

Online Published: February 27, 2022

URL: https://doi.org/10.46281/ijafr.v10i1.1635

\begin{abstract}
The purpose of this paper was to examine the moderating effect of board gender diversity on the relationship between corporate social responsibility (CSR) and real earnings management (REM). It drowns on French listed companies from 2005 to 2019. The results show that there is a positive relationship between CSR and REM. Our findings also show that this positive relation is moderated in firms with higher board gender diversity, mainly because female directors show a high socially responsible behaviour and are negatively associated with earnings management practices. Our results are robust to alternative board gender diversity measures, only after the quota law adoption. The positive relationship between CSR and REM suggests that companies with higher CSR performance are exposed to high discretionary behaviour. CSR can be strategically used by managers to hide unethical practices, such as real earnings management activities. In addition, the findings highlight the importance of board gender diversity in reducing agency costs and ensuring higher monitoring, particularly after the quota law adoption.
\end{abstract}

Keywords: Corporate Social Performance, Earnings Management, Financial Reporting, Stakeholder Engagement, Women on Boards.

JEL Classification Codes: G3, M14, M41.

\section{INTRODUCTION}

In a world increasingly marked by financial scandals, companies have witnessed a growing awareness about CSR-related issues. Firms basically invest in CSR to improve and defend their legitimacy and reputation. However, CSR engagement may sometimes be a disguise of firm misconduct and an instrument of manager entrenchment. Thereby, an ethical judgment of firms relies on CSR engagement, 
on the one hand, and/or on avoiding unethical behaviour, on the other. Earnings management is perceived as ethical misconduct (Almahrog, Aribi, \& Arun, 2018) that constitutes a central issue for investors and accounting academics. Walker (2013, p.446) defines earnings management (EM) as "The use of managerial discretion over (within GAAP) accounting choices, earnings reporting choices, and real economic decisions to influence how underlying economic events are reflected in one or more measures of earnings".

A stream of recent literature has focused on the impact of CSR engagement on firms' financial outcomes. Abundant literature has already been dedicated to studying the impact of CSR on the financial performance of companies (Blasi, Caporin, \& Fontini, 2018; Jia, 2020). The relationship between CSR and EM has also attracted extensive interest (Amar \& Chakroun, 2018; Pratiwi \& Siregar, 2019). The interest in this topic stems from the fact that both earnings management and CSR investment are decided by managers, who have various motives to invest in CSR; they can signal the quality of their financial reporting or use CSR to disguise the EM practices as well.

Although EM may take several forms, most previous studies focused on accruals earnings management (AEM), which consists of the discretionary choices of specific accounting treatment on certain transactions. El Diri (2017, p.13) stipulates that "Accruals earnings management does not influence the firms underlying economics but involves the change in the accounting presentation of these economics". Earnings management can also occur by taking certain economic decisions that may impact cash flows, investments or the firm's production, i.e., real earnings management. Roychowdhury (2006, p. 336) defines real earnings management as "Management actions that deviate from normal business practices, undertaken with the primary objective of meeting certain earnings thresholds". It consists of the manipulation of real activities, such as accelerating sales through discounts and credit payment facilities to the clients (Cohen \& Zarowin, 2010), overproduction to decrease the fixed costs per unit and consequently the sales cost (Chi, Lisic, \& Pevzner, 2011) and manipulating discretionary expenses (advertising expenses, research and development expenses, etc.). It is worth noting that there are other methods of earnings management, such as the smoothing method, the income shifting method and other advanced methods. REM is generally preferred to AEM because it is harder to detect, costly for firms to perform (Cohen, Dey, \& Lys, 2008) and perceived as less unethical compared to accruals manipulation (Hamid Hashim, \& Salleh, 2016). However, managers resort to REM to meet short term earnings targets, even at the expense of future profits for a higher current period income.

Our study is related to the new strand of literature that investigates the impact of CSR on EM based on a moderating variable. Prior empirical research works provide evidence on the difference between REM and AEM activities in their relationship with CSR (Bozzolan, Fabrizi, Mallin, \& Michelon, 2015; García-Sánchez \& García-Meca, 2017; Jordaan, De Klerk, \& De Villiers, 2018; Kim, Udawatte, \& Yin, 2019). First, while prior studies on the French context focused on AEM (Amar \& Chakroun, 2018; Ajina, Lakhal, \& Ayed, 2019), we aimed to define the effect of CSR on REM activities. Second, we emphasized the moderating role of board gender diversity in the CSR-REM relationship in the French context. To the best of our knowledge, only Ghaleb Qaderi, Almashaqbeh, \& Qasem, (2021) studied this relationship in the Jordanian context that is not comparable to the French one.

The remainder of this paper is structured as follows. Section 2 discusses the theoretical background, reviews the relevant literature and states the hypotheses. Section 3 specifies the data and models to test our hypotheses. The empirical results are described and discussed in section 4 . The final section concludes the paper.

\section{CSR Performance and Real Earnings Management}

THEORETICAL FRAMEWORK AND RESEARCH HYPOTHESES

In a recent study, Constantinescu and Kaptein (2020) have established a connection between ethical management at the managerial level and ethics management at the firm level. In fact, managers often use strategies related to firm performance (financial and social) and highlight managerial responsibility. Based on different motivations, managers may act ethically or opportunistically (Kim, Park, \& Wier, 
2012; Jordaan et al., 2018). Therefore, the CSR-REM relationship can be explained from two different perspectives.

The opportunistic perspective is mainly based on the traditional agency problem (Jensen \& Meckling, 1976) and the stakeholder theory (Freeman, 1984). Managers are appointed to firms to preserve shareholders' wealth. Because of information asymmetry between managers and shareholders, managers may have incentives to behave opportunistically in their decisions. CSR engagement may serve as an entrenchment mechanism to achieve managers' interests and manage earnings (Choi, Lee, \& Park, 2013). Managers may engage in CSR activities to conceal corporate misconduct and deflect stakeholders' attention. Therefore, CSR can be used by managers to hide earnings management (Muttakin, Khan, \& Azim, 2015) to avoid stakeholders' disapprobation.

According to the stakeholder theory, managers' decisions are required to consider the interests of the different stakeholders. While trying to satisfy a larger number of stakeholders and reach their different objectives, a greater information asymmetry may arise among the different parties, allowing the manager to manipulate earnings. Several empirical studies on the CSR-EM relationship supported this opportunistic perspective (Muttakin et al., 2015; López-González, Martinez-Ferrero, \& GarcíaMeca, 2019). Relying on a sample of Indonesian listed companies, Pratiwi and Siregar (2019) show that CSR commitment has a positive effect on tax avoidance and earnings management practices (AEM and REM). Moreover, the authors conclude that CSR disclosure aims to disguise opportunistic behaviour and maintain the firm image and legitimacy among stakeholders.

The ethical perspective finds support in the signalling and legitimacy theories. According to the former, CSR-affiliated firms tend to signal their performance by disclosing CSR information. Indeed, CSR information reduces information asymmetry and enhances information quality (Kim et al., 2012; Cui, Jo, \& Na, 2018). Managers opt for signalling the high quality of their firms by engaging in CSR, thus distinguishing them from their competitors. CSR disclosure will signal messages to the market on the firm's quality and the reliability of the information disclosed and consequently lower information asymmetry between insiders and outsiders. Since EM is extensively recognized as a major trait of financial reporting quality (Cohen et al., 2008; Kim et al., 2012; Zang, 2012) that is constrained by high information asymmetry, CSR affiliated firms are less likely to practise EM.

According to the legitimacy theory framework (Suchman, 1995), firm activities must comply with the social attitudes to survive.CSR plays a central role in maintaining a firm competitive position and legitimacy in society (Porter \& Kramer, 2006). By promoting CSR activities, a firm gains a better reputation and lowers its cost of capital (Martínez-Ferrero, Banerjee, \& García-Sánchez, 2016), which have advantageous effects on the manager's position (higher salary, higher labour market demand and better reputation). Hence, managers are expected to act ethically: disclose high information quality and engage in social and environmental activities. Kim et al. (2012) corroborate this perspective and find that CSR-affiliated firms disclose higher financial information quality to investors in the US market. Martínez-Ferrero et al. (2016) support the results of Kim et al. (2012), who concluded based on international data that managers of CSR-affiliated firms are more likely to avoid unethical behaviour such as earnings management. In short, highly socially responsible companies are more likely to show a commitment to ethical and accountable behaviour. They are likely to provide transparent and reliable financial information.

Previous studies on the CSR-EM relationship are inconclusive. The mixed results can be attributed to different contexts and, therefore, different studied legal frameworks and the different earnings management measures used. From a review of published papers between 2008 and 2016 by Rahman and Chowdhury (2020), we noticed that most studies use AEM as an EM measure (Almahrog et al., 2018; Amar \& Chakroun, 2018; López-González et al., 2019; Ajina et al., 2019). Generally, REMrelated studies jointly deal with AEM.

Studies examining the influence of CSR on both AEM and REM have shown that it varies depending on the used measure (Bozzolan et al., 2015; García-Sánchez \& García-Meca, 2017; Jordaan et al., 2018; Kim et al., 2019). Relying on a sample of Chinese firms, Kim et al. (2019) show that the higher the CSR activities are, the lower the earnings management will be, whether in AEM or REM. In 
a more in-depth study of the institutional framework of the different regions, the authors indicated that CSR engagement is positively related to real earnings management in state-controlled firms and firms situated in institutionally developed regions. This result is mainly attributed to the higher legitimacy risk to which these firms are exposed. Practising REM rather than AEM can also be explained by the fact that REM is harder to detect (Zang, 2012). In an international study of 24 countries, Bozzolan et al. (2015) stated that CSR involvement serves as a damper for REM but not AEM. Their results referred to the negative effect of REM on the future performance of a company which CSR-affiliated firms seek to avoid. Furthermore, Bozzolan et al. (2015) noted that REM activities even seem to be more restricted by CSR activities in a country with rigorous legal enforcement. Similar results were reported by GarcíaSánchez and García-Meca (2017) for a sample of 159 banks from 9 countries. A more recent study by Jordaan et al. (2018) on South African companies reveals that CSR activities are positively related to AEM but negatively related to REM activities. Unlike AEM, REM changes the actual firm transactions and affects the firm's cash flow, which has direct suboptimal business effects in the long term. Based on the ethical perspective and the results of prior research comparing CSR effects on AEM and REM, we can predict that firms with high CSR commitment are less likely to practice REM. Accordingly, our first hypothesis is as follows:

\section{$H_{1}$ : CSR performance is negatively related to REM}

\section{The Moderating Role of Board Gender Diversity on the Relationship between Corporate Social Responsibility and Earnings Management}

In what follows, we will focus on board gender diversity as a possible control mechanism that underlies the relationship between CSR and REM. Several previous works concluded that the board gender diversity might constitute a mechanism that inhibits discretionary behaviours (Lakhal, Aguir, Lakhal, \& Malek, 2015; Triki Damak, 2018; Orazalin, 2019; Mnif \& Cherif, 2020). Thus, board gender diversity could moderate the expected negative relationship between CSR and REM.

The interest in board gender diversity comes from the growing concerns about reaching gender equality on boards of directors and its central role in achieving social development and firm performance. This concern has led to the multiplication of new regulations that pressured or required companies to increase board gender diversity. For instance, in 2010, the European Commission launched a strategy to establish gender equality in all its policies according to several themes (equal pay for the same job, equality in decision-making, limit gender-based violence, etc.) between 2010 and 2015 . Several actions aiming to increase the representativeness of women on corporate boards have been launched by different countries (Norway, Italy, Belgium, the Netherlands, Sweden and Spain).In France, the AFEP-MEDEF Code of good governance was revised in 2010 to encourage companies to promote gender diversity on their boards of directors. Later, in January 2011, the "Copé-Zimmermann" law was enacted. This law requires that the representation of women on the boards of directors of French listed companies must reach $20 \%$ in 2014 and $40 \%$ in 2017.

According to Elstad and Ladegard (2012), the presence of women on the boards of directors changes its decision-making dynamic. We propose that there are two strategies influenced mainly by board gender diversity: corporate social investment and firm sustainability goals and the attitude towards their advisory and monitoring role in mitigating managerial opportunism.

The agency theory (Jensen \& Meckling, 1976) provides a basis for corporate governance through the use of internal and external mechanisms to protect the interests of shareholders, thus minimizing agency costs. Hill and Jones (1992) argue that corporate governance from a managerial point of view refers to the control and monitoring used to ensure that managers' actions are consistent with the interests of shareholders. The integration of diversity into the agency theoretical framework relies on establishing a relationship between the degree of diversity of the board of directors and the improvement of its control function and supervision of company management (Francoeur, Labelle, \& Sinclair-Desgagné, 2008). Gender diversity, as a characteristic of board composition, can act as a mechanism not only of monitoring and control (Francoeur et al., 2008; Adams \& Ferreira, 2009; Zalata, Ntim, Choudhry, 
Hassanein, \& Elzahar, 2019) but also of reducing agency costs and information asymmetry (Carter, Simkins, \& Simpson, 2003; Adams \& Ferreira, 2009), aligning managers' interests with those of the shareholders, improving the quality of reporting practices and preventing manipulation practices (Orazalin, 2019; Zalata et al., 2019; Maglio, Rey, Agliata, \& Lombardi, 2020).

The resource dependence theory (Pfeffer \& Salancik, 1978) highlights the board of directors' role in connecting a company with the external environment and accessing critical resources needed for survival (Hillman, Withers, \& Collins, 2009). Therefore, the board of directors is considered an internal governance mechanism ensuring the sustainability of the company, thus, managing its sustainability practices. Board diversity increases the resources available to the firm (Goodstein, Gautam, \& Boeker, 1994), expands its network connection (Siciliano, 1996) and improves problem-solving skills (Vafaei, Ahmed, \& Mather, 2015). According to Carter et al. (2003), greater diversity allows for a better understanding of particular market conditions, brings more creativity and quality to decision-making and efficiency to problem-solving. Nadeem, Zaman, \& Saleem (2017) suggest that the presence of women on boards represents a significant body of knowledge, skills, network connections and, ultimately, business advantages that can positively influence stakeholder perceptions of a company's reputation and a company's bottom line.

Regarding EM, a stream of literature supports the idea that board gender diversity enhances earnings quality (Srinidhi, Gul, \& Tsui, 2011; Lara, Osma, Mora, \& Scapin, 2017) and the quality of financial information (Pucheta-Martínez, Bel-Oms, \& Olcina-Sempere, 2016). Therefore, in this sense and with respect to the agency theory, women directors are effective in their monitoring role, mitigate managerial opportunism measured as AEM (Lakhal et al., 2015; Triki Damak, 2018; Zalata et al., 2019) and thus diminish the classical agency conflict between managers and shareholders. These authors suggest that women on board are less likely to engage in unethical practices (i.e., EM and fraud) and are concerned about preserving the company's reputation. Thus, women on boards are more averse than their male counterparts to being detected using EM. This argument is supported by Hurley and Choudhary (2020), who state that female board members are risk-averse and reduce firm risk-taking.

The inherent argument of the orientation of women to socially responsible behaviour arises from the social role theory (Eagly, 1987), which suggests that women are more inclined to follow a stakeholder-oriented leadership style that improves stakeholders' perception of the firm by enhancing CSR performance. Several studies state that ethical judgment differs between men and women (Adams $\&$ Funk, 2012). In fact, women are more sensitive to ethics and are more likely to reason based on care, compassion, gaining trust; therefore, more likely to exhibit more ethical behaviour (Zalata et al., 2019). Researchers assert that women on boards of directors are likely to improve CSR performance and solve CSR concerns (Hussain, Rigoni, \& Orij, 2018). Nekhili, Nagati, Chtioui, \& Nekhili (2017) provide evidence that board gender diversity plays a crucial role in the pertinence of voluntary CSR reporting. Moreover, Board gender diversity has a positive effect on the level of CSR reporting (Issa \& Fang, 2019) and the quality of sustainability reports (Al-Shaer \& Zaman, 2016).

To the best of our knowledge, the study of Ghaleb et al. (2021) is the first to investigate the moderating effect of corporate board gender diversity on the CSR-REM relationship. The authors focused on an emerging market (Jordan) where board gender diversity is low compared to developed markets.

From the above, we base our premise on two issues: (i) the higher CSR commitment of firms with gender diversified boards and (ii) firms with gender diversified boards exhibit a lower REM level. Thus, we analyze the effect of CSR on REM in firms with gender diversified boards and propose the following hypothesis:

\section{$\mathrm{H}_{2}$ : Board gender diversity moderates the relationship between CSR performance and REM}




\section{Sample and Data}

\section{METHOD}

The initial sample of this study consisted of firms listed on the SBF120 index for the period spanning 2005-2019. The choice of the study period is justified by mandatory adoption of IFRS standards since January 1st, 2005 for all listed European companies, which has led to a significant change in the applied accounting policies. Following prior studies, we excluded the financial companies from the initial sample since disclosure requirements and accounting rules significantly differ from those of nonfinancial firms, which may affect the results (Jordaan et al., 2018; Almahorg et al., 2018). After excluding observations with missing information, a final sample of 1,144 firm year-observations spanning fifteen years (2005-2019) was available to tests the hypotheses.

CSR data were collected from the Asset 4 database, the financial data were obtained from the Datastream database, while corporate governance data were hand collected from firms' annual reports.

Table 1. Sample selection

\begin{tabular}{|c|c|}
\hline & Number of observations \\
\hline French firms listed on the SBF 120 index & 1800 \\
\hline $\begin{array}{l}\text { 39 Firms belonging to the financial } \\
\text { sector }\end{array}$ & 585 \\
\hline$-\quad$ Observations with missing data & 71 \\
\hline \multicolumn{1}{|c|}{ Total } & 1144 \\
\hline
\end{tabular}

\section{Measures}

\section{Real Earnings Management}

In this study, the real earnings management was measured using the Roychowdhury (2006) model that highlights the managerial decisions related to manipulating sales transactions and consists of three components.

The first component is related to the decrease in the operating cash flows $(C F O)$ as a result of sales discounts and lenient credit terms to boost sales and improve earnings over a specific period. The abnormal operating cash flow $(a b-C F O)$ is calculated as the difference between the normal $C F O$ and the actual $C F O$ based on sales level and changes in sales according to the following regression:

$$
\text { CFOit/Aavg }=\alpha+\alpha 1(1 / \text { Aavg })+\beta 1(\text { Salesit/Aavg })+\beta 2(\text { SSalesit } / \text { Aavg })+\varepsilon i t
$$

Where $C F O_{i t}$ represents the operating cash flows during year $\mathrm{t}$; Salesit represents the sales during year $\mathrm{t}$; $\triangle$ Salesit $_{\text {it }}$ represents the change in sales compared to last year; $A_{\text {avg }}$ is the average total assets of the beginning and ending asset balance. All variables are scaled by average total assets $\left(A_{\text {avg }}\right)$ of the beginning and ending asset balances to avoid any heteroscedasticity.

The second component is related to reducing discretionary expenses to improve earnings and current cash flows. Discretionary expenses include research and development, advertising as well as selling, general and administrative expenses. Therefore, the abnormal discretionary expenses $(a b$ $D I S E X P)$ are calculated according to the following regression:

$$
\text { DiscExp }_{i t} / \text { Aavg }=\alpha+\alpha_{1}(1 / \text { Aavg })+\beta_{1}\left(\text { Sales }_{i t-1} / \text { Aavg }\right)+\varepsilon_{\mathrm{it}}
$$

Where DiscExp represents the discretionary expenses that include research and development, advertising and selling, general and administrative expenses; Salesit_l is the sales of the previous year used instead of the current year sales (Sales $i$ ) to abstain from the mechanical decrease in discretionary 
expenses in case of managing sales upwards during the current period; $A_{\text {avg }}$ is the average total assets of the beginning and ending asset balance.

The third component is related to the increase in the operating costs, namely high production level to lower fixed costs per unit, decrease the cost of goods sold and accordingly improve earnings. The abnormal production costs $(a b-P R O D)$ are estimated according to the following regression:

$$
\text { Prodit/Aavg }=\alpha+\alpha 1(1 / \text { Aavg })+\beta 1(\text { Salesit/Aavg })+\beta 2(\Delta \text { Salesit/Aavg })+\beta 3(\Delta \text { Salesit-1/Aavg })+\text { cit }
$$

Where Prod represents the production costs which include the costs of goods sold in addition to the change in inventory during the period; Sales represents the sales for the current period; $\Delta$ Salesit $_{i t}$ represents the change in sales during the current period; $\Delta$ Salesit_l $_{\text {I }}$ represents the change in sales during to the previous period; $A_{\text {avg }}$ is the average total assets of the beginning and ending asset balance. The abnormal production costs are calculated as the difference between the normal production costs and the actual production costs.

Following previous studies (Bozzolan et al., 2015; Jordaan et al., 2018; Kim et al., 2019), we constructed the overall REM measure by combining its three individual measures:

$$
R E M i t=-a b \_C F O i t-a b \_D I S E X P i t+a b \_P R O D i t
$$

The $a b-C F O$ and $a b-D I S E X P$ are multiplied by -1 to reflect the upward EM. Indeed, when managers engage in REM, we expect lower $a b-C F O$ and $a b-D I S E X P$ levels and higher $a b-P R O D$ level. A higher $R E M$ measure indicates higher earning management.

\section{CSR Performance and Different CSR Dimensions}

To measure CSR performance (CSR), we relied on the ESG global score extracted from the Asset 4 Thomson Reuters database. The ESG score is the most commonly used CSR performance measure in recent literature (Blasi et al., 2018; López-González et al., 2019).

\section{Board Gender Diversity}

Board gender diversity (BGD) is measured as the proportion of women on the board, calculated as the number of female directors divided by the total number of directors sitting on the corporate board.

\section{Control Variables}

Following previous studies on the relationship between CSR and EM (Bozzolan et al., 2015; Jordaan et al., 2018; Kim et al., 2019; López-González et al., 2019; Ghaleb et al., 2021), we included a series of control variables in our regression. First, we controlled for board characteristics: Board size (BSIZE) is measured as the number of directors on the board and board member independence (BINDEP) as the proportion of independent directors sitting on the board. CEO duality (DUAL) is measured by a binary variable taking 1 if the functions of chairman of the board and CEO are occupied by the same person and 0 otherwise. The specific skills (SP-SKILLS) variable is measured as the percentage of board members who have either an industry-specific background or a strong financial background. We also controlled for the existence of an audit committee on the board (AUD-COM), which is measured by a binary variable taking 1 if there is an audit committee on the board and 0 otherwise. The audit committee independence (AUD-COMINDEP) is calculated as the proportion of independent directors in the audit committee. Second, we took into account firm characteristics, such as firm performance (PERFORM) measured as the return on equity (ROE) ratio, the market to book ratio (MTB) used as a proxy of the firm's growth prospects, firm leverage (LEV) measured by the total net debt to total assets ratio and firm size (SIZE) measured as the natural logarithm of total capital. We also controlled for whether the financial crises (CRISES) have an impact on earnings management activities by including a dummy variable taking the value 1 for the years 2008 and 2009 and 0 otherwise. 


\section{Regression Model}

To avoid endogeneity problems generated by reverse causalities and omitted variables, we used the GMM estimation approach following Blundell and Bond (1998). First, we estimated the following model, which captures the impact of the CSR performance level on REM by controlling for the autocorrelated structure of the dependent variable:

$$
R E M_{i t}=\beta_{0}+\beta_{1} R E M_{i t-1}+\beta_{2} \text { CSR }_{i t}+\sum \gamma_{i} * \text { Control Variables } i t+\varepsilon_{i t}
$$

Where $\varepsilon_{i t}$ is the error term for firm i during a period t.

To examine the moderating effect of board gender diversity on the CSR-REM relationship described in our basic model, we regressed REM on the CSR variable, lagged board gender diversity variable and the interaction between these two variables

$$
R E M_{i t}=\beta_{0}+\beta_{1} R E M_{i t-1}+\beta_{2} C S R_{i t}+\beta_{3} B G D_{i t-1}+\beta_{4} C S R * B G D_{i t-1}+\sum \gamma_{i} * \text { Control Variables } i t+
$$

We considered two specification tests to address the consistency of the GMM estimator. The first is the Sargan test of over-identifying restrictions, which tests the reliability of the instruments, and the second is the Arellano and Bond (1991) test for second-order autocorrelation.

\section{Descriptive Statistics}

\section{RESULTS AND DISCUSSION}

Table 2 displays the descriptive statistics of the variables used in the analysis for the entire sample. The data show that REM is on average 0.2696. The mean CSR score is 0.5789 out of 1 ; thus, the firms in our sample are relatively socially responsible. Boards comprise, on average, about 13 directors. The percentage of women on the board is on average $24.83 \%$. Besides, $49.79 \%$ of board members are independent, and $38.77 \%$ have specific skills. Almost all the companies in our sample have an audit committee on their boards, with independent directors representing $72.39 \%$. Table II also shows that, on average, ROE is $11.66 \%$, firm size is 15.6227 , leverage is $28.01 \%$, and market to book value is 2.2018 .

\section{Univariate Analysis}

The mean differences of REM and CSR are shown in Table 3. For this analysis, we created two groups based on the median of the mediating variable (board gender diversity). One group consisted of firms with board gender diversity greater than the median of the whole sample, and the other group is composed of firms with board gender diversity lower than the median of the whole sample.

Table 3 shows that the mean difference between REM exhibits a positive sign, as predicted, and is statistically significant. Thus, this finding suggests that firms with a higher board gender diversity exhibit lower REM than those with lower board gender diversity. As expected, CSR exhibits a negative sign and is statistically significant. In fact, firms with higher board gender diversity are more likely to exhibit higher CSR. This finding is in line with previous studies (Hussain et al., 2018).

Table 2. Descriptive statistics

\begin{tabular}{|l|c|c|c|c|}
\hline & Mean & S.D & Minimum & Maximum \\
\hline REM & 0.2686 & 0.2615 & -0.2833 & 1.3908 \\
\hline $\boldsymbol{C S R}$ & 0.5789 & 0.1923 & 0 & 0.9403 \\
\hline $\boldsymbol{B G D}$ & 0.2483 & 0.1685 & 0 & 0.83 \\
\hline $\boldsymbol{B S I Z E}$ & 13.0132 & 3.4632 & 4 & 26 \\
\hline BINDEP & 0.4979 & 0.2117 & 0 & 1 \\
\hline DUAL & 0.5044 & 0.5002 & 0 & 1 \\
\hline $\boldsymbol{A U D}$-COM & 0.9659 & 0.1815 & 0 & 1 \\
\hline
\end{tabular}




\begin{tabular}{|l|c|c|c|c|}
\hline AUD-COM INDEP & 0.7239 & 0.2927 & 0 & 1 \\
\hline SP-SKILLS & 0.3877 & 0.1961 & 0 & 1 \\
\hline PERFORM & 0.1166 & 0.4588 & -2.875 & 13.018 \\
\hline MTB & 2.2018 & 2.0157 & -8.98 & 15.96 \\
\hline LEV & 0.2801 & 0.2339 & 0 & 2.538 \\
\hline SIZE & 15.6227 & 1.3075 & 10.43 & 18.81 \\
\hline
\end{tabular}

Table 3. Mean comparison test Board gender diversity

\begin{tabular}{|l|c|c|c|c|}
\hline & $\boldsymbol{B} G D(>=$ median $)$ & $\boldsymbol{B} G \boldsymbol{C}(<$ median $)$ & \multicolumn{2}{|c|}{ Mean } \\
\cline { 4 - 5 } & Mean & Mean & Difference & p-value \\
\hline $\boldsymbol{R E M}$ & 0.2395 & 0.2949 & 0.0554 & 0.0003 \\
\hline $\boldsymbol{C S R}$ & 0.6491 & 0.5156 & -0.1335 & 0.0000 \\
\hline
\end{tabular}

\section{Multivariate Analysis}

In Table 4, we present the correlation matrix and variance inflation factor (VIF) results. As can be seen from the table, all the coefficients are lower than 0.6, all the VIF values are less than 10 , and the average of the VIFs is lower than 2. Thus, there is no serious multicollinearity

Table 5 reports the System GMM regression results of the effect of CSR on REM. The ArellanoBond test and the Sargan test indicate the absence of second-order serial correlation and the validity of the instruments, respectively. Prior real earnings management practice, measured by the one-year lagged value of REM, is an important determinant of REM. The results also show that CSR is positively related to REM, which leads us to reject our first hypothesis (H1). This result is consistent with the opportunistic perspective and is in line with several previous studies (Muttakin et al., 2015; López-González et al., 2019; Pratiwi \& Siregar, 2019). We support that the higher the CSR commitment, the higher REM activities are. The manager's opportunistic incentives are observed to affect real earnings management activities. By investing in CSR, managers divert stakeholders' attention and try to disguise unethical practices.

Table 4. Pairwise correlation matrix

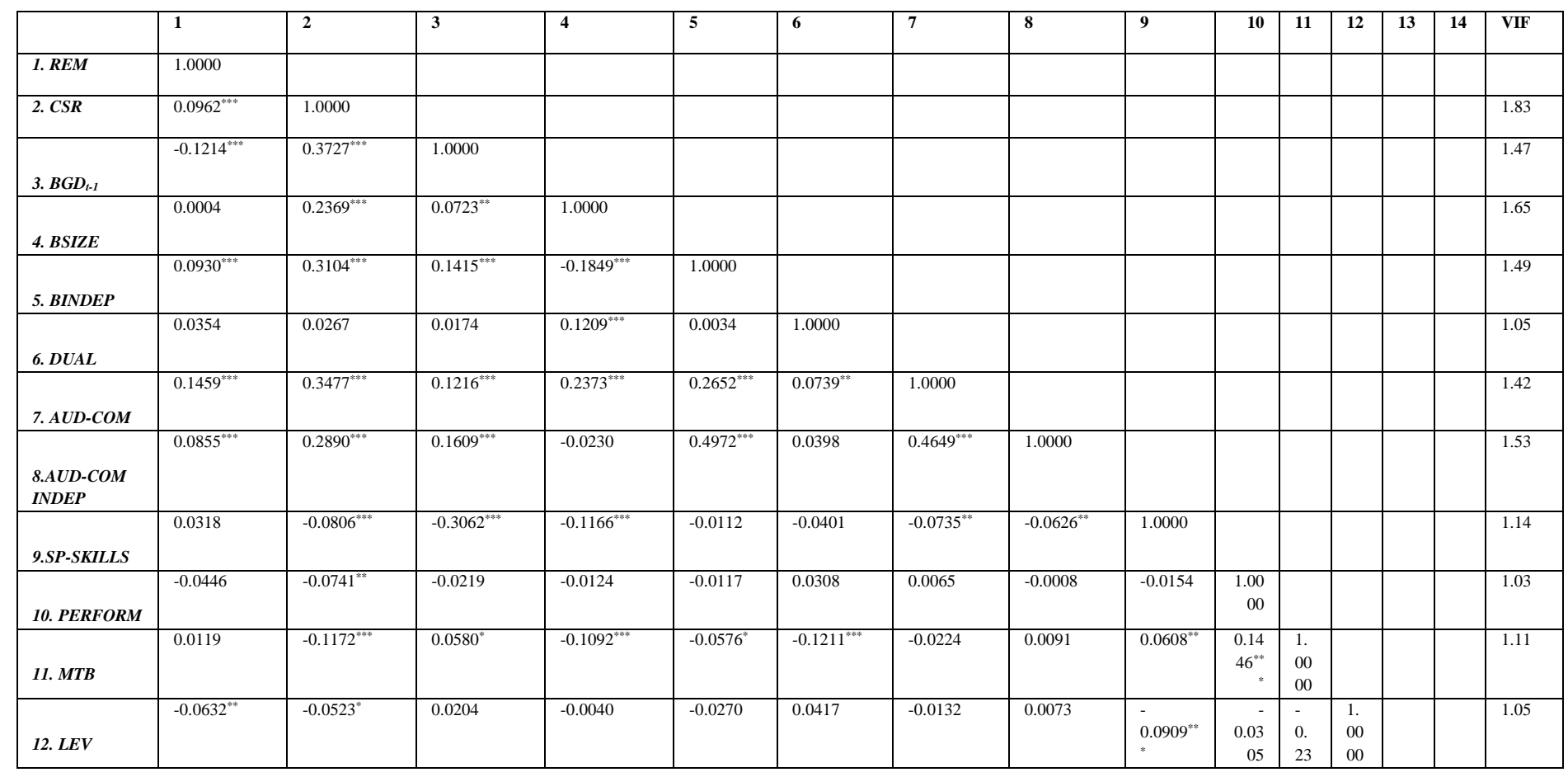




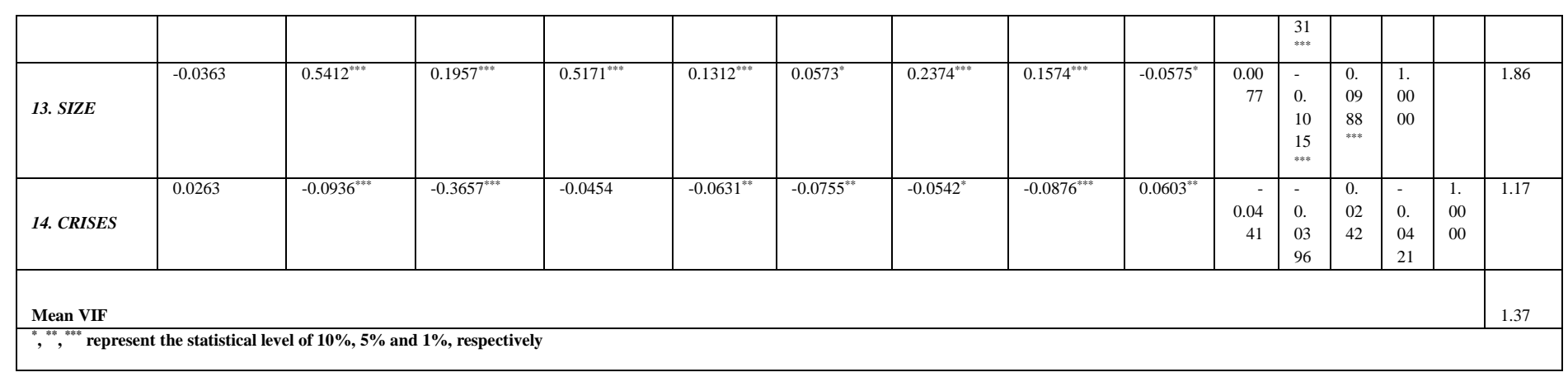

Table 5. Regression results of CSR on REM

\begin{tabular}{|l|c|c|}
\hline & Coefficient & P-value \\
\hline REM $\boldsymbol{t}$ - & 0.7762 & 0.000 \\
\hline $\boldsymbol{C S R}$ & 0.0579 & 0.000 \\
\hline $\boldsymbol{B S I Z E}$ & 0.0013 & 0.000 \\
\hline BINDEP & -0.0131 & 0.000 \\
\hline DUAL & -0.0111 & 0.000 \\
\hline $\boldsymbol{A U D}$-COM & -0.0285 & 0.000 \\
\hline $\boldsymbol{A U D}$-COM INDEP & -0.0092 & 0.000 \\
\hline SP-SKILLS & -0.0052 & 0.025 \\
\hline $\boldsymbol{P E R F O R M}$ & -0.0038 & 0.000 \\
\hline $\boldsymbol{M T B}$ & -0.0018 & 0.000 \\
\hline LEV & -0.1778 & 0.000 \\
\hline SIZE & -0.0664 & 0.000 \\
\hline $\boldsymbol{C R I S E S}$ & -0.0172 & 0.000 \\
\hline Constant term & 1.1471 & 0.000 \\
\hline Sargan test (Chi2; p-value) & & $66.07(0.99)$ \\
\hline Arellano-Bond test (z; p-value) & & $-0.94(0.35)$ \\
\hline
\end{tabular}

The results of the possible moderating role of board gender diversity in the relationship between CSR and REM are reported in Table 6. CSR has a positive and significant effect on the REM measure. Specifically, the higher the CSR performance is, the higher the level of real earnings management will be. Regarding the board gender diversity effect, we note a negative and significant impact on REM activities. This result supports the idea that female directors constrain earnings management and is in line with several prior studies on the French context (Lakhal et al., 2015; Triki Damak, 2018).

Table 6. The moderating effect of board gender diversity on CSR and REM relationship

\begin{tabular}{|c|c|c|}
\hline & Coefficient & P-value \\
\hline $\operatorname{REM}_{t-1}$ & 0.7371 & 0.000 \\
\hline CSR & 0.1074 & 0.000 \\
\hline$B G D_{t-1}$ & -0.0419 & 0.000 \\
\hline$C S R * B G D_{t-1}$ & -0.0360 & 0.033 \\
\hline BSIZE & 0.0017 & 0.000 \\
\hline BINDEP & -0.0012 & 0.696 \\
\hline$D U A L$ & -0.0091 & 0.000 \\
\hline$A U D-C O M$ & -0.0490 & 0.000 \\
\hline AUD-COM INDEP & -0.0075 & 0.000 \\
\hline
\end{tabular}




\begin{tabular}{|l|c|c|}
\hline SP-SKILLS & -0.0112 & 0.000 \\
\hline PERFORM & -0.0025 & 0.015 \\
\hline MTB & -0.0013 & 0.000 \\
\hline LEV & -0.1708 & 0.000 \\
\hline SIZE & -0.0656 & 0.000 \\
\hline CRISES & -0.0217 & 0.000 \\
\hline Constant term & 1.1345 & 0.000 \\
\hline Sargan test (Chi2; p-value) & \multicolumn{2}{|c|}{$64.47(0.99)$} \\
\hline Arellano-Bond test (z; p-value) & $-0.70(0.48)$ \\
\hline
\end{tabular}

Accounting for the moderating role board gender diversity plays, the interaction term (CSR*BGD) reveals a positive and significant effect on the REM measure. Our results show that the positive impact of CSR on EM practices is lower in firms with greater board gender diversity. This result allows us to support our second hypothesis $(\mathrm{H} 2)$ empirically. This moderating effect responds to higher CSR and lower EM commitment of firms with higher board gender diversity. First, female directors are supposed to reduce the agency problem as they are more effective in monitoring and control (Adams \& Ferreira, 2009; Zalata et al., 2019). Second, board gender diversity enhances CSR commitment to improve reputation among stakeholders. Regarding the control variables, the results show that firms having directors with specific skills, audit committee and higher audit committee independence tend to engage in REM less. Also, we prove that big firms and those with higher performance are less likely to engage in REM activities. However, the number of directors on the board is positively related to REM.

\section{Robustness Checks}

\section{Alternative measure of board gender diversity}

We used an alternative measure of gender diversity, i.e., the Shannon index, to test the robustness of our results. This Index measures the specific diversity of an environment. It makes it possible to quantify the heterogeneity of the board of directors (Shannon, 1948). This measure takes into account both the number of directors of each gender category (men/women) and their equal distribution and is calculated as follows:

$$
\text { SHANNON }=-\sum_{i=1}^{N} P_{i} \ln P_{i}
$$

Where $\mathrm{P}_{\mathrm{i}}$ refers to the percentage of a given gender, male or female, in relation to the total number of directors, and $\mathrm{N}$ is the number of categories (Men/Women), which is equal to 2 for our study. Table 7 provides the estimation results that remain consistent with those displayed in Table 6.

Table 7. The moderating effect of Shannon index on CSR and REM relationship

\begin{tabular}{|c|c|c|}
\hline & Coefficient & P-value \\
\hline$R_{E M} M_{t-1}$ & 0.7066 & 0.000 \\
\hline CSR & 0.1126 & 0.000 \\
\hline SHANNON $_{t-1}$ & -0.0376 & 0.001 \\
\hline$C_{S S R} * S H A N N O N_{t-1}$ & -0.0439 & 0.008 \\
\hline BSIZE & 0.0013 & 0.000 \\
\hline BINDEP & 0.0015 & 0.661 \\
\hline$D U A L$ & -0.0092 & 0.000 \\
\hline$A U D-C O M$ & 0.0054 & 0.001 \\
\hline AUD-COM INDEP & -0.0037 & 0.000 \\
\hline SP-SKILLS & -0.0229 & 0.000 \\
\hline
\end{tabular}




\begin{tabular}{|l|c|c|}
\hline PERFORM & 0.0005 & 0.602 \\
\hline MTB & -0.0011 & 0.000 \\
\hline LEV & -0.1495 & 0.000 \\
\hline SIZE & -0.0554 & 0.000 \\
\hline CRISES & -0.0247 & 0.000 \\
\hline Constant term & 0.09495 & 0.000 \\
\hline Sargan test (Chi2; p-value) & $63.02(0.99)$ \\
\hline Arellano-Bond test (z; p-value) & $-1.98(0.05)$ \\
\hline
\end{tabular}

\section{Before and After Quota Law}

The Copé-Zimmermann law was promulgated in 2011 to enhance female representation on boards of directors of French firms. This law was a turning point in board gender diversity. In fact, companies have abruptly increased gender diversity in their boards to comply with this law. To assess the effect of this law, we divided the study period into two sub-periods, i.e., 2005-2010 and 2011-2019, and reestimated the models. Table VIII presents the estimation results of the two sub-periods.

Our results are robust for the period following the adoption of the quota law. Results show that CSR is positively and significantly associated with REM, but board gender diversity and interaction term have a negative and significant sign. However, board gender diversity has no significant impact on REM activities before the quota law adoption. Furthermore, the interaction term between CSR and board gender diversity is statistically non-significant; thus, there is no mediating effect. Our results highlight the role of the quota law adoption in the structural change in board composition characteristics and mechanisms. This finding is in line with the critical mass theory, which refers to the particular number of personnel needed to influence policy and change (Kanter, 1977), specifically when it comes to the implementation of the quota law (Atinc, Srivastava, \& Taneja, 2021).

Table 8. The moderating effect of board gender diversity on CSR and REM relationship: before/after the Copé-Zimmermann law

\begin{tabular}{|c|c|c|}
\hline & 2005-2010 & 2011-2019 \\
\hline$R E M_{t-1}$ & $0.3652^{* * *}$ & $0.7442^{* * *}$ \\
\hline CSR & $0.0636^{*}$ & $0.0831^{* * * *}$ \\
\hline$B G D_{t-1}$ & -0.0352 & $-0.0322^{* * * *}$ \\
\hline$C S R * B G D_{t-1}$ & -0.0746 & $-0.0329^{* * * *}$ \\
\hline BSIZE & 0.0020 & 0.0003 \\
\hline BINDEP & -0.0004 & $-0.0228^{* * * *}$ \\
\hline DUAL & 0.0216 & 0.0001 \\
\hline$A U D-C O M$ & 0.0242 & $-0.1094^{* * * *}$ \\
\hline AUD-COM INDEP & $-0.0540^{* * *}$ & $-0.0006^{* * * *}$ \\
\hline SP-SKILLS & -0.0081 & 0.0079 \\
\hline PERFORM & $-0.0051^{* * * *}$ & $-0.0021^{* *}$ \\
\hline$M T B$ & $0.0076^{* * *}$ & $-0.0014^{* *}$ \\
\hline$L E V$ & $-0.1622^{* *}$ & $-0.1340^{* * * *}$ \\
\hline SIZE & $-0.0283^{* *}$ & $-0.0685^{* * *}$ \\
\hline Constant term & $0.5881^{* * *}$ & $1.2597^{* * *}$ \\
\hline Sargan test (Chi2; p-value) & $19.76(0.10)$ & $63.84(0.98)$ \\
\hline Arellano-Bond test (z; p-value) & $1.39(0.17)$ & $-1.9(0.06)$ \\
\hline
\end{tabular}




\section{CONCLUSION}

In this paper, we shed light on the impact of corporate social responsibility on real earnings management and investigated the moderating role of board gender diversity in the French firms listed on the SBF 120 index from 2005 to 2019.

Our findings show that firms with high CSR commitment are more likely to engage in real earnings management activities. Thus, our results are in line with the opportunistic perspective, which asserts that CSR activities are motivated by the manager's incentives to hide ethical misconduct, i.e., REM activities. The study further investigated whether board gender diversity moderates the CSR-REM relationship. In the light of the descriptive statistics, our findings show that board gender diversified firms are more likely to invest in CSR and more reluctant to manage earnings than those with less gender diversity. Our estimation results show that board gender diversity plays a negative moderating role in the positive CSR-REM relationship. In other words, the positive effect of CSR on REM is less pronounced in firms with higher board gender diversity.

The findings of this study have several practical implications. First, they inform the users of the financial statements, mainly investors, on the reliability of using CSR as an indicator of firm ethics. Second, they enable regulators to get viable knowledge on the importance of board gender diversity in improving financial information quality and support the orientation towards increasing board gender diversity on boards, particularly the quota law adoption.

Conceptualization: S. Boukattaya

\section{AUTHOR CONTRIBUTIONS}

Data Curation: S. Boukattaya

Formal Analysis: S. Boukattaya, S. Halaoua

Funding Acquisition: S. Boukattaya, S. Halaoua

Investigation: $S$. Boukattaya

Methodology: S. Boukattaya, S. Halaoua

Project Administration: S. Boukattaya, S. Halaoua

Resources: S. Boukattaya, S. Halaoua

Software: S. Boukattaya

Supervision: S. Boukattaya

Validation: S. Boukattaya, S. Halaoua

Visualization: S. Boukattaya

Writing - Original Draft: S. Boukattaya

Writing - Review \& Editing: S. Boukattaya, S. Halaoua

\section{CONFLICT OF INTEREST STATEMENT}

The authors declare that they have no competing interests.

\section{ACKNOWLEDGEMENT}

All authors contributed equally to the conception and design of the study.

\section{REFERENCES}

Adams, R. B., \& Ferreira, D. (2009). Women in the boardroom and their impact on governance and $\begin{array}{lll}\text { performance. Journal of } & \text { financial }\end{array}$ https://doi.org/10.1016/j.jfineco.2008.10.007

Adams, R. B., \& Funk, P. (2012). Beyond the glass ceiling: Does gender matter?. Management science, 58(2), 219-235. https://doi.org/10.1287/mnsc.1110.1452

Ajina, A., Lakhal, F., \& Ayed, S. (2019). Does corporate social responsibility reduce earnings management? The moderating role of corporate governance and ownership. Management 
international/International Management/Gestiòn Internacional,23(2),

45-55. https://doi.org/10.7202/1060030ar

Almahrog, Y., Aribi, Z. A., \& Arun, T. (2018). Earnings management and corporate social responsibility: UK evidence. Journal of Financial Reporting and Accounting. https://doi.org/10.1108/JFRA-11-2016-0092

Al-Shaer, H., \& Zaman, M. (2016). Board gender diversity and sustainability reporting quality. Journal of Contemporary Accounting \& $210-222$. https://doi.org/10.1016/j.jcae.2016.09.001

Amar, A. B., \& Chakroun, S. (2018). Do dimensions of corporate social responsibility affect earnings management? Evidence from France. Journal of Financial Reporting and Accounting, 16(2), 348-370. https://doi.org/10.1108/JFRA-05-2017-0033

Arellano, M., \& Bond, S. (1991). Some tests of specification for panel data: Monte Carlo evidence and an application to employment equations. The review of economic studies, 58(2), 277-297. https://doi.org/10.2307/2297968

Atinc, G., Srivastava, S., \& Taneja, S. (2021). The impact of gender quotas on corporate boards: a crosscountry comparative study. Journal of Management and Governance, 1-22. https://doi.org/10.1007/s10997-020-09562-6

Blasi, S., Caporin, M., \& Fontini, F. (2018). A multidimensional analysis of the relationship between corporate social responsibility and firms' economic performance. Ecological Economics, 147, 218-229. https://doi.org/10.1016/j.ecolecon.2018.01.014

Blundell, R., \& Bond, S. (1998). Initial conditions and moment restrictions in dynamic panel data models. Journal of econometrics,87(1), 115-143. https://doi.org/10.1016/S03044076(98)00009-8

Bozzolan, S., Fabrizi, M., Mallin, C. A., \& Michelon, G. (2015). Corporate social responsibility and earnings quality: International evidence. The International Journal of Accounting, 50(4), 361396. https://doi.org/10.1016/j.intacc.2015.10.003

Carter, D. A., Simkins, B. J., \& Simpson, W. G. (2003). Corporate governance, board diversity, and firm value. Financial review, 38(1), 33-53. https://doi.org/10.1111/1540-6288.00034

Chi, W., Lisic, L. L., \& Pevzner, M. (2011). Is enhanced audit quality associated with greater real earnings management?. Accounting horizons, 25(2), 315-335. https://doi.org/10.2308/acch10025

Choi, B. B., Lee, D., \& Park, Y. (2013). Corporate Social Responsibility, Corporate Governance and Earnings Quality: Evidence from K orea. Corporate Governance: An International Review, 21(5), 447-467. https://doi.org/10.1111/corg.12033

Cohen, D. A., \& Zarowin, P. (2010). Accrual-based and real earnings management activities around seasoned equity offerings. Journal of accounting and Economics, 50(1), 2-19. https://doi.org/10.1016/j.jacceco.2010.01.002 
Cohen, D. A., Dey, A., \& Lys, T. Z. (2008). Real and accrual-based earnings management in the preand post-Sarbanes-Oxley periods. The accounting review, 83(3), 757-787. https://doi.org/10.2308/accr.2008.83.3.757

Constantinescu, M., \& Kaptein, M. (2020). Ethics management and ethical management: Mapping criteria and interventions to support responsible management practice. In O. Laasch, R. Suddaby, R. E. Freeman and D. Jamali (Eds.), Research handbook of responsible management (pp. 155-174). Edward Elgar Publishing: Cheltenham.

Cui, J., Jo, H., \& Na, H. (2018). Does corporate social responsibility affect information asymmetry?. Journal of Business Ethics, 148(3), 549-572. https://doi.org/10.1007/s10551-0153003-8

Eagly, A. H. (1987). Reporting Sex Differences, American Psychologist, 42(7), 756-757. https://psycnet.apa.org/doi/10.1037/0003-066X.42.7.755

El Diri, M. (2017). Introduction to earnings management. Springer: New York.

Elstad, B., \& Ladegard, G. (2012). Women on corporate boards: key influencers or tokens?. Journal of Management \& Governance, 16(4), 595-615. https://doi.org/10.1007/s10997-010-9165-y

Francoeur, C., Labelle, R., \& Sinclair-Desgagné, B. (2008). Gender diversity in corporate governance and top management, Journal of Business Ethics, 81(1), 83-95. https://doi.org/10.1007/s10551007-9482-5

Freeman, R. E. (1984). Strategic management: A stakeholder theory, Journal of Management Studies, 39(1), 1-21.

García-Sánchez, I. M., \& García-Meca, E. (2017). CSR engagement and earnings quality in banks. The moderating role of institutional factors. Corporate Social Responsibility and Environmental Management, 24(2), 145-158. https://doi.org/10.1002/csr.1405

Ghaleb, B. A. A., Qaderi, S. A., Almashaqbeh, A., \& Qasem, A. (2021). Corporate social responsibility, board gender diversity and real earnings management: The case of Jordan. Cogent Business \& Management, 8(1), 1883222. https://doi.org/10.1080/23311975.2021.1883222

Goodstein, J., Gautam, K., \& Boeker, W. (1994). The effects of board size and diversity on strategic change. Strategic management journal, 15(3), 241-250. https://doi.org/10.1002/smj.4250150305

Hamid, F., Hashim, H. A., \& Salleh, Z. (2016). Auditor's view on acceptability of clients' earnings management practices. Corporate Ownership \& Control, 13(4), 535-541. https://doi.org/10.22495/cocv13i4c4p2

Hill, C. W., \& Jones, T. M. (1992). Stakeholder-agency theory. Journal of management studies, 29(2), 131-154. https://doi.org/10.1111/j.1467-6486.1992.tb00657.x

Hillman, A. J., Withers, M. C., \& Collins, B. J. (2009). Resource dependence theory: A review. Journal of management, 35(6), 1404-1427. https://doi.org/10.1177/0149206309343469 
Hurley, D., \& Choudhary, A. (2020). Role of gender and corporate risk taking. Corporate Governance: The International Journal of Business in Society, 20(3), 383-399. https://doi.org/10.1108/CG10-2018-0313

Hussain, N., Rigoni, U., \& Orij, R. P. (2018). Corporate governance and sustainability performance: Analysis of triple bottom line performance. Journal of Business Ethics, 149(2), 411-432. https://doi.org/10.1007/s10551-016-3099-5

Issa, A., \& Fang, H. X. (2019). The impact of board gender diversity on corporate social responsibility in the Arab Gulf states. Gender in Management: An International Journal, 34(7), 577605. https://doi.org/10.1108/GM-07-2018-0087

Jensen, M. C., \& Meckling, W. H. (1976). Theory of the firm: Managerial behavior, agency costs and ownership structure. Journal of financial economics, 3(4), 305-360. https://doi.org/10.1016/0304-405X(76)90026-X

Jia, X. (2020). Corporate social responsibility activities and firm performance: The moderating role of strategic emphasis and industry competition. Corporate Social Responsibility and Environmental Management, 27(1), 65-73. https://doi.org/10.1002/csr.1774

Jordaan, L. A., De Klerk, M., \& De Villiers, C. J. (2018). Corporate social responsibility and earnings management of South African companies. South African Journal of Economic and Management Sciences, 21(1), 1-13. .https://doi.org/10.4102/sajems.v21i1.1849

Kanter R.M. (1977). Some Effects of Proportions on Group Life. In P.P. Rieker, E. Carmen (Eds.), The gender gap in psychotherapy (pp. 53-78), Springer: Boston. https://doi.org/10.1007/9781-4684-4754-5_5

Kim, S. H., Udawatte, P., \& Yin, J. (2019). The effects of corporate social responsibility on real and accrual-based earnings management: Evidence from China. Australian Accounting Review, 29(3), 580-594. https://doi.org/10.1111/auar.12235

Kim, Y., Park, M. S., \& Wier, B. (2012). Is earnings quality associated with corporate social responsibility?. The accounting review, 87(3), 761-796. https://doi.org/10.2308/accr-10209

Lakhal, F., Aguir, A., Lakhal, N., \& Malek, A. (2015). Do women on boards and in top management reduce earnings management? Evidence in France. Journal of Applied Business Research (JABR), 31(3), 1107-1118. https://doi.org/10.19030/jabr.v31i3.9236

Lara, J. M. G., Osma, B. G., Mora, A., \& Scapin, M. (2017). The monitoring role of female directors over accounting quality. Journal of Corporate Finance, 45, 651-668. https://doi.org/10.1016/j.jcorpfin.2017.05.016

López-González, E., Martinez-Ferrero, J., \& García-Meca, E. (2019). Does corporate social responsibility affect earnings management? Evidence from family firms. Revista de Contabilidad-Spanish Accounting Review, 22(2), 233-247. https://doi.org/10.6018/rcsar.349601

Maglio, R., Rey, A., Agliata, F., \& Lombardi, R. (2020). Connecting earnings management and corporate social responsibility: A renewed perspective. Corporate Social Responsibility and Environmental Management, 27(2), 1108-1116. https://doi.org/10.1002/csr.1868 
Martínez-Ferrero, J., Banerjee, S., \& García-Sánchez, I. M. (2016). Corporate social responsibility as a strategic shield against costs of earnings management practices. Journal of Business Ethics, 133(2), 305-324. https://doi.org/10.1007/s10551-014-2399-x

Mnif, Y., \& Cherif, I. (2020). Female board directorship and earnings management. Pacific Accounting Review, 33 (1), 114-141. https://doi.org/10.1108/PAR-04-2020-0049

Muttakin, M. B., Khan, A., \& Azim, M. I. (2015). Corporate social responsibility disclosures and earnings quality: are they a reflection of managers' opportunistic behavior?. Managerial Auditing Journal, 30(3), 277-298. https://doi.org/10.1108/MAJ-02-2014-0997

Nadeem, M., Zaman, R., \& Saleem, I. (2017). Boardroom gender diversity and corporate sustainability practices: Evidence from Australian Securities Exchange listed firms. Journal of Cleaner Production, 149, 874-885. https://doi.org/10.1016/j.jclepro.2017.02.141

Nekhili, M., Nagati, H., Chtioui, T., \& Nekhili, A. (2017). Gender-diverse board and the relevance of voluntary CSR reporting. International Review of Financial Analysis, 50, 81-100. https://doi.org/10.1016/j.irfa.2017.02.003

Orazalin, N. (2019). Board gender diversity, corporate governance, and earnings management: Evidence from an emerging market. Gender in Management, 35(1), 3760. https://doi.org/10.1108/GM-03-2018-0027

Pfeffer, J., \& Salancik, G.R. (1978). The External Control of Organizations: A Resource Dependence Perspective. Harper \&Row: New York.

Porter, M. E., \& Kramer, M. R. (2006). The link between competitive advantage and corporate social responsibility, Harvard business review, 84(12), 78-92.

Pratiwi, I. S., \& Siregar, S. V. (2019). The effect of corporate social responsibility on tax avoidance and earnings management: the moderating role of political connections. International Journal of Business, 24(3), 229-248.

Pucheta-Martínez, M. C., Bel-Oms, I., \& Olcina-Sempere, G. (2016). Corporate governance, female directors and quality of financial information. Business Ethics: A European Review, 25(4), $363-$ 385. https://doi.org/10.1111/beer.12123

Rahman, M., \& Chowdhury, S. (2020). Relationship between Corporate Social Responsibility and Earnings Management: A Systematic Review of Measurement Methods, International Journal of Trend in Scientific Research and Development, 4(2), pp. 389-397. http://www.ijtsrd.com/papers/ijtsrd29987.pdf

Roychowdhury, S. (2006). Earnings management through real activities manipulation. Journal of accounting and economics, 42(3), 335-370. https://doi.org/10.1016/j.jacceco.2006.01.002

Shannon, C. E. (1948). A mathematical theory of communication. The Bell system technical journal, 27(3), 379-423. https://doi.org/10.1002/j.1538-7305.1948.tb01338.x.

Siciliano, J. I. (1996). The relationship of board member diversity to organizational $\begin{array}{lllr}\text { performance. Journal of } & \text { Business } & \text { Ethics, 15(12), }\end{array}$ https://doi.org/10.1007/BF00411816 
Srinidhi, B. I. N., Gul, F. A., \& Tsui, J. (2011). Female directors and earnings quality. Contemporary accounting research, 28(5), 1610-1644. https://doi.org/10.1111/j.1911-3846.2011.01071.x

Suchman, M. C. (1995). Managing legitimacy: Strategic and institutional approaches. Academy of management review, 20(3), 571-610. https://doi.org/10.5465/amr.1995.9508080331

Triki Damak, S. (2018). Gender diverse board and earnings management: evidence from French listed companies. Sustainability Accounting, Management and Policy Journal, 9(3), 289312. https://doi.org/10.1108/SAMPJ-08-2017-0088

Vafaei, A., Ahmed, K., \& Mather, P. (2015). Board diversity and financial performance in the top 500 Australian firms. Australian Accounting Review, 25(4), 413-427. https://doi.org/10.1111/auar.12068

Walker, M. (2013). How far can we trust earnings numbers? What research tells us about earnings management. Accounting and Business Research,43(4), 445-481. https://doi.org/10.1080/00014788.2013.785823

Zalata, A. M., Ntim, C. G., Choudhry, T., Hassanein, A., \& Elzahar, H. (2019). Female directors and managerial opportunism: Monitoring versus advisory female directors. The Leadership Quarterly, 30(5), 101309. https://doi.org/10.1016/j.leaqua.2019.101309

Zang, A. Y. (2012). Evidence on the trade-off between real activities manipulation and accrual-based earnings management. The accounting review, 87(2), 675-703. https://doi.org/10.2308/accr10196

\section{Copyrights}

Copyright for this article is retained by the author(s), with first publication rights granted to the journal. This is an open-access article distributed under the terms and conditions of the Creative Commons Attribution license (https://creativecommons.org/licenses/by/4.0). 